Reprod. Nutr. Dévelop., 1988, 28 (5), 1217-1224

\title{
The role of the epididymis during maturation of mammalian spermatozoa in vivo and in vitro
}

\author{
H. D. M. MOORE, Caroline A. SMITH
}

MRC/AFRC Comparative Physiology Research Group,

Institute of Zoology, Zoologica/ Society of London, Regent's Park, London, NW7 4RY, U.K.

\section{Introduction.}

Fertilization in mammals involves a series of recognition processes between the spermatozoon and the oocyte. These interactions are often species and cell specific (Moore and Bedford, 1983; Bedford, 1981). For example, human spermatozoa will normally bind to oocytes and not to other somatic cells. They also display limited specificity towards foreign eggs and in fact will only attach to the eggs of Great Apes (Bedford, 1977). Such experiments suggest that mammalian spermatozoa have specific receptors on their surface which are able to recognize complementary binding sites on the zona pellucida. During evolution the deployment of these receptor mechanisms has become inextricably linked to the physiology and biochemistry of the whole animal. In order to understand how sperm/egg recognition processes may operate it is important to know when gamete surface molecules are first expressed and their nature.

Numerous studies have shown that mammalian spermatozoa acquire fertilizing capacity on passing through the proximal epididymis (Bedford, 1975; Moore, Hartman and Pryor, 1983). In the rabbit and hamster, studies using surgical manipulations of the excurrent ducts in situ (Orgebin-Crist et al., 1975 ; Horan and Bedford, 1972) or using antibodies (Lea, Petrusz and French, 1978 ; Moore, 1981 ; Moore and Hartman, 1984) have established that there is a positive contribution by the epididymal epithelium to the development of this maturation. But the exact nature of the factors responsible for this maturation have yet to be identified. Unfortunately, the relationship between the epididymal epithelium and luminal spermatozoa has proved difficult to study in vivo. We have therefore investigated the possibility of carrying out in vitro sperm maturation and have used the hamster as an animal model (Moore, Hartman and Smith, 1986).

\section{In vitro culture of hamster epididymal epithelium.}

The microenvironment of the epididymal lumen is generated by the secretory and absorptive activity of the epithelium under the control of androgens, directly from the testis in rete testis fluid, or via the peripheral circulation. In situ this site 
is not easily sampled, say by micropuncture technique, without altering epididymal function. Organ and tissue culture methods have therefore been attempted to mimic epididymal function. Principal cells cultured in vitro show normal morphological features for several days (Kierszebaum et al., 1981 ; Klinefelter et al., 1982 ; Joshi, 1985). Moreover, organ culture of epididymal tubules will induce limited sperm maturation although access to the lumen is still restricted (Orgebin-Crist and Jahad, 1979 ; Cuasnicú et al., 1984).

To provide a simplified system to study epididymal function we have developed a cell culture preparation in which the ultrastructural epithelial architecture remains largely intact but spermatozoa can gain complete access to the apical surface of the epithelial cells (Moore, Hartman and Smith, 1986). Briefly, the method involves digesting lengths of tubule from hamster corpus or cauda epididymidis with collagenase in order to remove connective tissue. The tubules are then split along their longitudinal axis using fine needles. This procedure forms plaques of epithelium which in culture turn into spheres of tissue with epithelium facing outwards. The culture medium consists of RPMI 1640 supplemented with $10 \%$ foetal calf serum, and containing $1 \mu \mathrm{M}$ sodium pyruvate, $100 \mathrm{nM}$ insulin, $200 \mathrm{nM}$ hydrocortisone, $200 \mathrm{nM}$ testosterone, $1 \mu \mathrm{M}$ dihydrotestosterone, $5 \mu \mathrm{g}$ transferrin $/ \mathrm{ml}$ and $1 \mu \mathrm{g}$ retinol $/ \mathrm{ml}$. The medium is filtered before use and supplemented with streptomycin and penicillin. Epithelial preparations are cultured in $5 \% \mathrm{CO}$ in air and within 24 hours many tissue spheres form. At high magnification epithelial cells (with microvilli present) can be observed around the edge of these balls of tissue (fig. 1). Electron microscopy revealed that spheres of epithelium consisted of an outer layer of epithelial cells, a basal lamina and an inner sub epithelial layer consisting of contractile myoid cells and fibroblasts. When tissue was prepared from adult males, spermatozoa also became entrapped within the balls as they formed. In general, epithelium cultured for 4-6 days displays a morphology consistent with secretory and absorptive function.

The secretory nature of the epithelial culture has been assessed using a monoclonal antibody (C5) against a $34 \mathrm{Kd}$ protein (Smith, Hartman and Moore, 1986) first synthesised and secreted by principal cells in the proximal corpus epididymidis but not produced by cells in the caput or initial segment regions (fig. 2). On cultured epithelium this antigen is observed on the apical surface of principal cells for at least the first 4 days of culture and sometimes up to 7 days. In the absence of testosterone and dihydrotestosterone, antigen could not be detected after the second day of culture suggesting that its synthesis and secretion was under the control of androgens.

\section{Development of the fertilizing capacity of hamster spermatozoa in vitro.}

In the hamster, spermatozoa are fully fertile when recovered from the proximal cauda epididymidis but display low fertilizing capacity (5-15\%) when recovered from the distal corpus region. This lack of fertility is associated with a reduced 


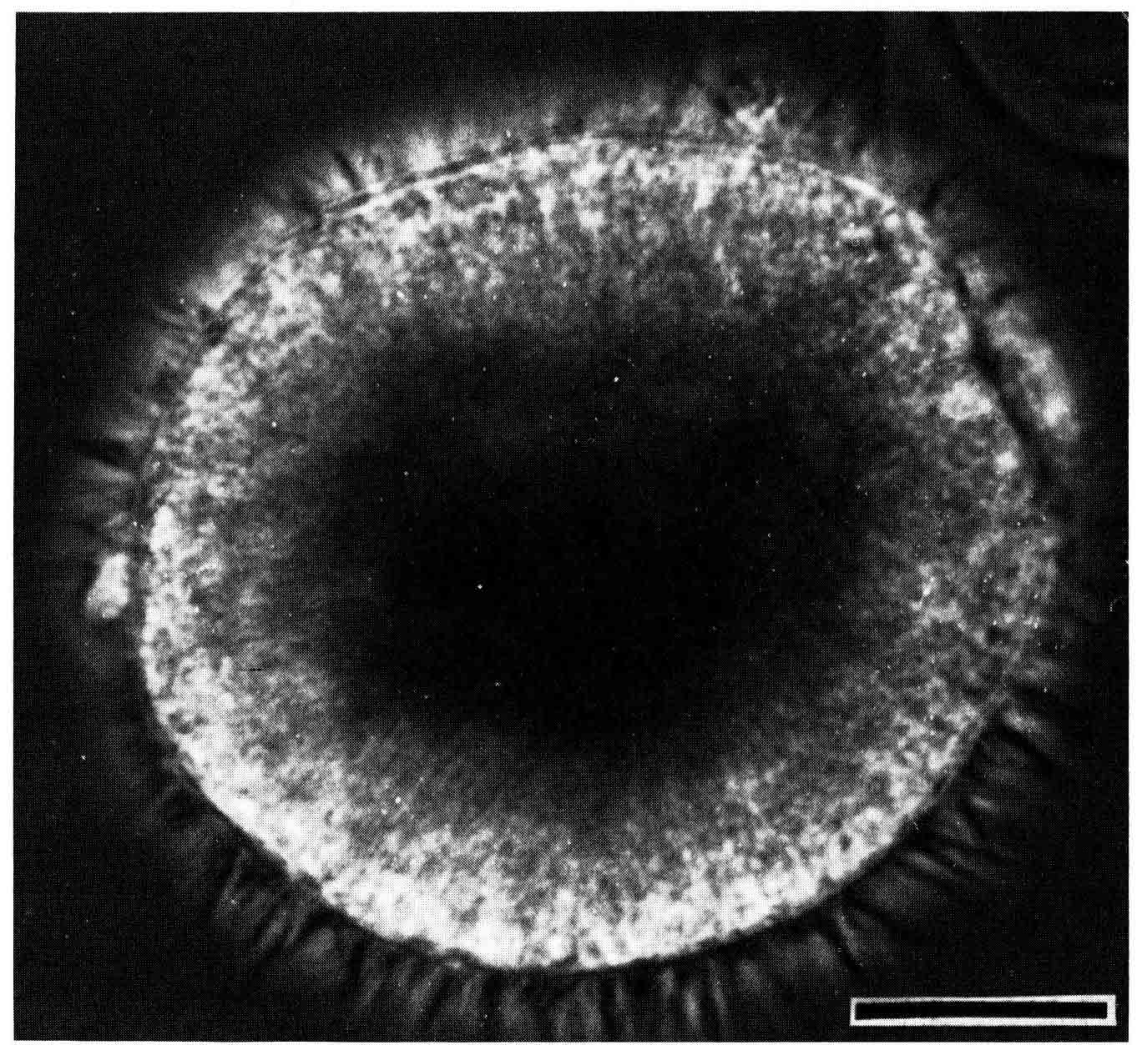

FIG. 1. - A micrograph of an epithelial ball after 24 hours of culture. Microvilli are clearly visible on the surface. Phase contrast. Bar $=10 \mu \mathrm{m}$.

ability to bind to the zona pellucida and slow progressive motility. To examine whether in vitro maturation of immature spermatozoa could be achieved, spermatozoa were recovered from the corpus region and incubated with 3 day-old epithelial cultures for 6 hours in $50 \mu \mathrm{l}$ microdrops under oil. Sperm fertility was then assessed by in vitro fertilization or in vivo insemination of females 2-3 hours before the estimated time of ovulation (Moore and Hartman, 1986). Although a pronounced increase in the binding of spermatozoa to the zona pellucida was evident following incubation with epithelial culture there was no significant increase in fertilizing ability compared with control spermatozoa. This acquisition of zona-binding receptors on spermatozoa after co-culture was in agreement with previous work by (Cuasnicú et al., 1984) but failure to promote fertility was contrary to the report again by Blaquier's group (GonzalesEchieverría et al., 1.984) where maturation was successful with epididymal protein extract.

Since spermatozoa from the distal corpus region do not exhibit the same motility characteristics as those from the cauda epididymidis it was surmised that this could be the reason for the lack of fertility. By ligating the hamster epididymis

Reproduction, Nutrition, Développement, $n^{\circ} 5 / 88-2$ 


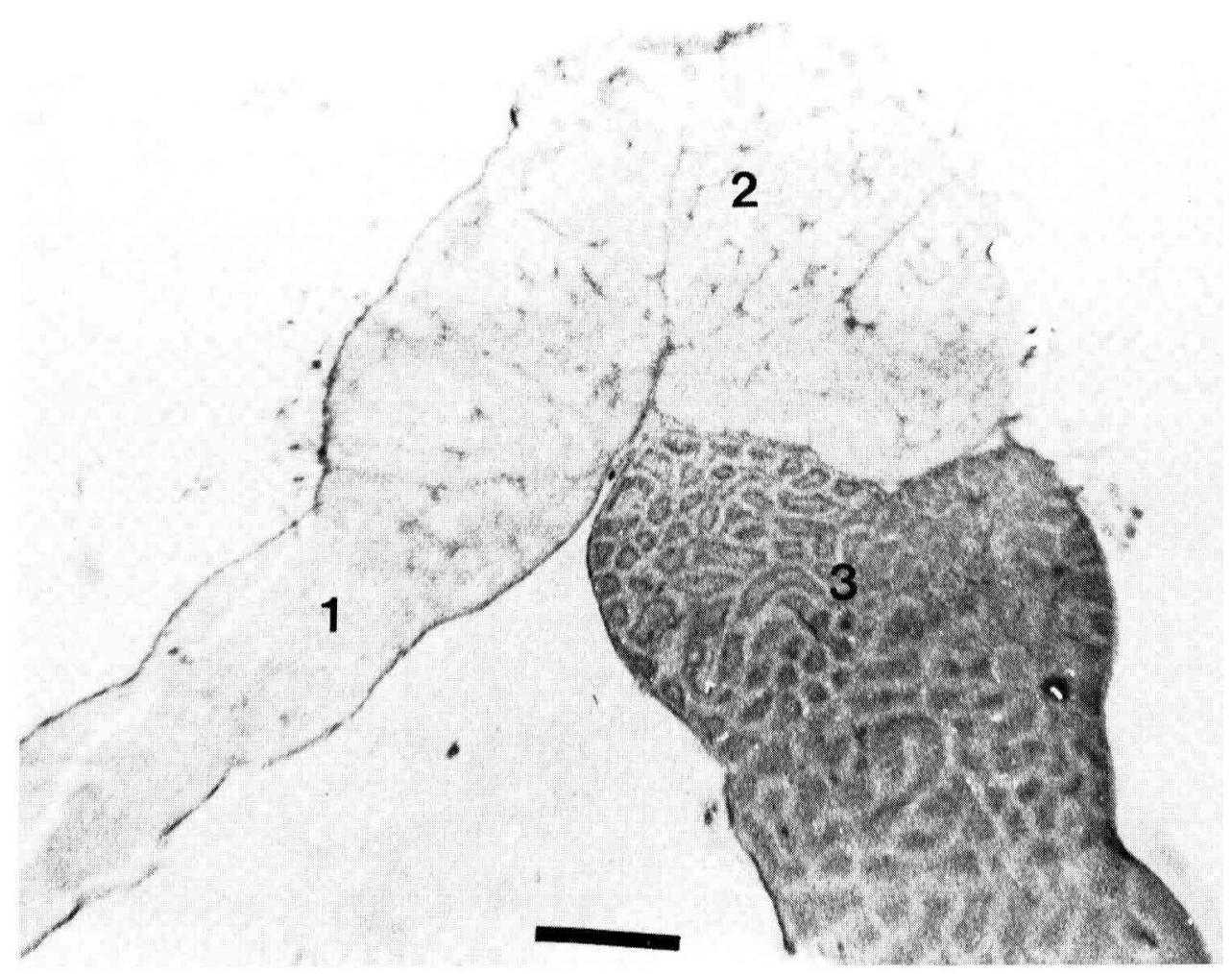

FIG. 2. - A low power micrograph of a section of proximal epididymis from an adult hamster following immunocytochemical localisation with C5 antibody. Staining was limited to the proximal corpus, first on the epithelium and more distally on spermatozoa. Bar $=1 \mathrm{~mm}$.

at the junction of the distal corpus and proximal cauda regions for 3 days, spermatozoa recovered from the corpus region attain increased progressive motility and head to head autoagglutination but still have low fertility. However, the incubation of these spermatozoa with epididymal epithelium for 6 hours resulted in a significant increase in fertilising capacity in vitro or in vivo to $30-40 \%$. The fertilising ability of distal corpus spermatozoa incubated with 3 day old cultures without androgens, or with 8-12 days old epithelial cells with fibroblast overgrowth, or without epithelial cells remained low (5\%). Since all the sperm samples maintained their motility and underwent similar capacitation and fertilization conditions it can be concluded that factors present in the culture of proximal cauda epithelium promoted the final stages of hamster sperm maturation (fig. 3).

One of the processes of maturation probably involves the acquisition of the receptor for recognizing the oocyte although it remains to be determined how this receptor is formed. Studies with $\mathrm{C} 5$ monoclonal antibody indicate that epitopes can be specifically transferred from the epididymal epithelium to spermatozoa in vitro. If spermatozoa from the caput region are incubated with corpus epithelial 

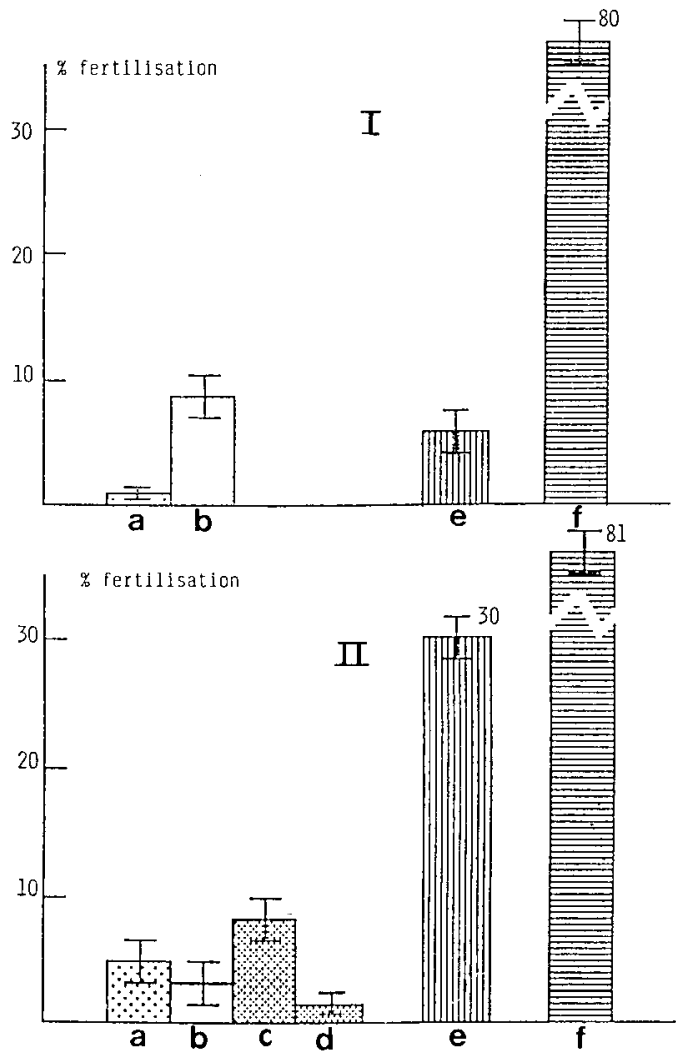

FIG. 3. - Histograms of the fertilising ability in vitro of spermatozoa from the distal corpus epididymidis of intact (I) and ligated (II) adu/t hamsters following pre-incubation treatments. (a) culture without androgen; (b) without incubation; (c) old epithelial culture ; (d) without epithelial culture; (e) culture with androgen; ( $f$ ) cauda sperm positive control.

cultures they acquire antigen to $\mathrm{C} 5$ on their post-acrosomal region and on their annulus (fig. 4). This limited binding of determinant suggests a specific coupling to the sperm surface. The membrane changes were concomitant with the induction of forward motility in a proportion of spermatozoa. While the molecular weight of 34000 for the $\mathrm{C5}$ determinant would indicate that it is not forward motility protein, the specific binding to the annulus might well induce changes in the flagellum movement.

\section{Conclusion.}

These in vitro studies support previous in situ investigations and extend our understanding of the role of the epididymal epithelium during mammalian sperm maturation. The use of immunological techniques with polyclonal and monoclo- 


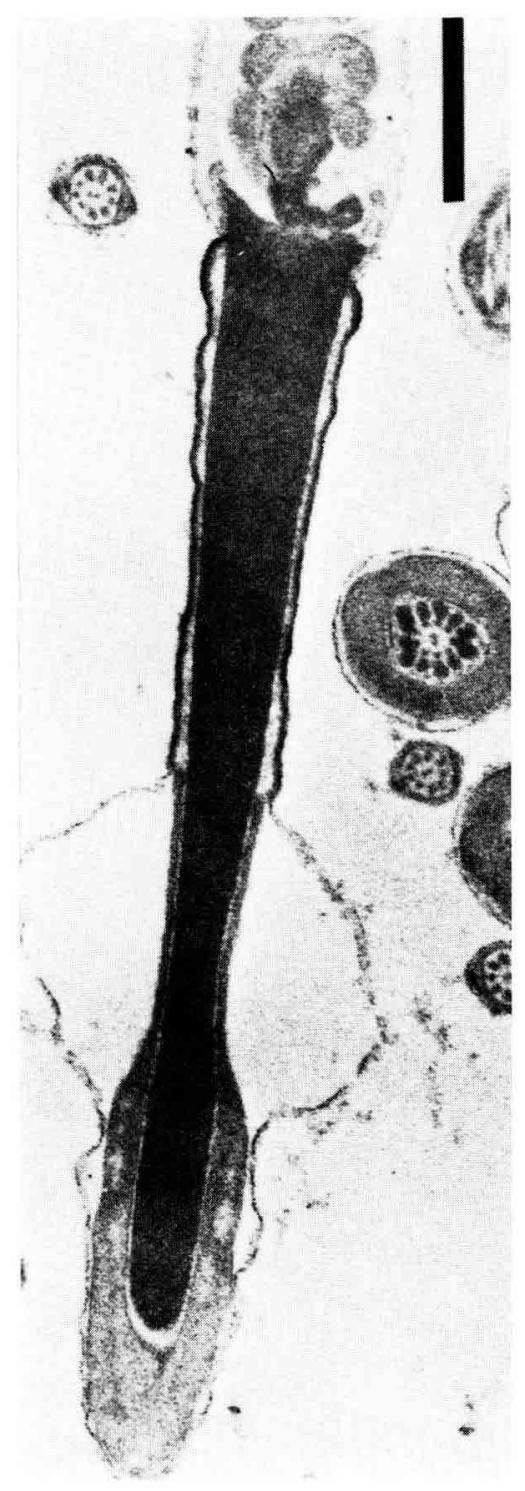

FIG. 4. - Electron micrograph of a section of hamster spermatozoa from the corpus epididymidis after immunolocalisation for C5 determinant. Reaction product is present on the post-acrosomal region. Bar $=1 \mu \mathrm{m}$.

nal antibodies have shown conclusively that mammalian sperm surface proteins and glycoproteins undergo extensive but specific reorganization during epididymal maturation due to (a) inherent membrane modifications related to morphological reorganization and membrane fluidity changes and (b) the addition of components (protein or sugars) secreted by the epididymal epithelium under the control of androgens. Recent investigations indicate that the foundation for these changes is first laid down during spermatogenesis. 
In our laboratory we are currently devising methods to culture human epididymal epithelium from patients undergoing epididymovasectomy. These techniques may allow us to directly observe human sperm maturation processes in vitro.

$5^{e}$ Congrès de la Société d'Andrologie de langue française, Paris, décembre 1987.

Acknowledgements. - This study was supported by grants from the Ford Foundation, the Medical Research Council and the Agriculture and Food Research Council.

Résumé. Le rôle de l'épididyme au cours de la maturation in vivo et in vitro des spermatozoïdes chez les mammifères.

Chez les mammifères les spermatozoïdes ne sont pas fécondants à la sortie du testicule et n'acquièrent leur capacité à féconder qu'après leur transit à travers les régions proximales de l'épididyme. Chez l'homme la maturation finale des spermatozoïdes s'effectuerait dans le corps de l'épididyme, ce qui serait en accord avec les résultats obtenus par des techniques chirurgicales telles que l'épididymovasostomie.

Afin d'explorer les processus de la maturation des spermatozoïdes des méthodes de culture in vitro ont été mises au point. Chez le hamster l'activité fonctionnelle de l'épithélium épididymaire a été maintenue in vitro pendant 5 jours. Des spermatozoïdes immatures incubés avec ces cultures acquièrent leur pouvoir fécondant. L'usage d'anticorps monoclonaux a permis de montrer que des produits sécrétoires spécifiques sont transférés de la surface des cellules principales épididymaires en culture sur les spermatozoïdes. Des travaux similaires sur l'épithélium épididymaire humain sont maintenant en cours de développement. Les résultats indiquent que l'activité fonctionnelle des cellules épithéliales peut être maintenue en culture et devraient permettre une exploration plus poussée de la maturation des spermatozoïdes humains.

\section{References}

BEDFORD J. M., 1975. Maturation, transport and fate of spermatozoa in the epididymis. In R. O. GREEP and D.W. HAMILTON. Handbook of physiology, Endocrinology V, section 7 pp. 303-317. Am. Physiol. Soc., Washington.

BEDFORD J. M., 1977. Sperm/egg interaction : the specificity of human spermatozoa. Anat. Rec., 188, 477-488.

BEDFORD J. M., 1981. Why mammalian gametes don't mix. Nature (Lond.), 291, 286-287.

CUASNICÚ P. S., GONZALES-ECHEVERRIA F., PIAZZA A., BLAQUIER J. A., 1984. Addition of androgens to cultured hamster epididymis increases zona recognition by immature spermatozoa. J. Reprod. Fert., 70, 541-547.

GONZALES-ECHEVERRIA F., CUASNICU் P. S., PIAZZA A., PIÑEIRO L., BLAQUIER J.A., 1984. Addition of an androgen-free epididymal protein extract increases the ability of immature hamster spermatozoa to fertilize in vivo and in vitro. J. Reprod. Fert., 71, 433-437.

HORAN A. H., BEDFORD J. M., 1972. Development of the fertilizing ability of spermatozoa in the epididymis of the syrian hamster. J. Reprod. Fert., 30, 417-423.

JOSHI M. S., 1985. Isolation and cell culture of the epithelial cells of cauda epididymis of the bull. Biol. Reprod., 33, 187-200.

KIERSZENBAUM A. L., LEA O., PETRUSZ P., FRENCH F. S., TRES L. L., 1981. Isolation, culture and immunocytochemistry characterization of epididymal epithelial cells from pubertal and adult rats. Proc. nat. Acad. Sci., U.S.A., 78, 1675-1679. 
KLINEFELTER G. R., AMANN R. P., HAMMERSTEDT R. H., 1982. Culture of principal cells from the rat caput epididymidis. Biol. Reprod., 26, 885-901.

LEA O. A., PETRUSZ P., FRENCH F. S., 1978. Purification and localisation of acidic epididymal glycoprotein (AEG) : a sperm coating protein secreted by the rat epididymis. Int. J. Androl., Suppl. 2, 592-605.

MOORE H. D. M., 1981. Glycoprotein secretions of the epididymis in the rabbit and hamster: localisation on epididymal spermatozoa and the effect of specific antibodies on fertilization in vivo. J. exp. Zool., 215, 77-85.

MOORE H. D. M., BEDFORD J. M., 1983. The interaction of mammalian gametes in the female, 453-497. In HARTMANN J. F., Mechanism and control of animal fertilization. Acad. Press, New York.

MOORE H. D. M., HARTMAN T. D., 1984. Localization by monoclonal antibodies of various surface antigens of hamster spermatozoa and the effect of antibody on fertilization in vitro. J. Reprod. Fert., 70, 175-183.

MOORE H. D. M., HARTMAN T. D., 1986. In vitro development of the fertilizing ability of hamster epididymal spermatozoa after co-culture with epithelium from the proximal cauda epididymidis. J. Reprod. Fert., 78, 347-352.

MOORE H. D. M., HARTMAN T. D., PRYOR J. P., 1983. Development of the oocyte penetrating capacity of spermatozoa in the human epididymis. Int. J. Androl., 6, 310-318.

MOORE H. D. M., HARTMAN T. D., SMITH C. A., 1986. In vitro culture of hamster epididymal epithelium and induction of sperm motility. J. Reprod. Fert., 78, 327-336.

ORGEBIN-CRIST M.-C., JAHAD N., 1979. The maturation of rabbit epididymal spermatozoa in organ culture stimulated by epididymal cytoplasmic extracts. Biol. Reprod., 21, 511-516.

ORGEBIN-CRIST M.-C., DANZO B. J., DAVIES J., 1975. Endocrine control of the development and maintenance of sperm fertilizing ability in the epididymis. In R. O. GREEP and D.W. HAMILTON, Handbook of Physiology. Male reproductive systems, section 7, vol. V, pp. 319-338. Am. Physiol. Soc. Washington.

SMITH C. A., HARTMAN T. D., MOORE H. D. M., 1986. A determinant of Mr 34000 expressed by hamster epididymal epithelium binds specifically to spermatozoa in co-culture. J. Reprod. Fert., 78, 337-345. 